University of Nebraska - Lincoln

DigitalCommons@University of Nebraska - Lincoln

6-25-2007

\title{
Patterns of Fish Diversity in a Mainstem Missouri River Reservoir and Associated Delta in South Dakota and Nebraska, USA
}

\author{
Mark A. Kaemingk \\ University of Nebraska - Lincoln, mkaemingk2@unl.edu \\ Brian D.S. Graeb \\ South Dakota State University, Brian.Graeb@sdstate.edu \\ Christopher W. Hoagstrom \\ South Dakota State University \\ David W. Willis \\ South Dakota State University
}

Follow this and additional works at: https://digitalcommons.unl.edu/natrespapers

Part of the Natural Resources and Conservation Commons, Natural Resources Management and Policy Commons, and the Other Environmental Sciences Commons

Kaemingk, Mark A.; Graeb, Brian D.S.; Hoagstrom, Christopher W.; and Willis, David W., "Patterns of Fish Diversity in a Mainstem Missouri River Reservoir and Associated Delta in South Dakota and Nebraska, USA" (2007). Papers in Natural Resources. 690.

https://digitalcommons.unl.edu/natrespapers/690

This Article is brought to you for free and open access by the Natural Resources, School of at DigitalCommons@University of Nebraska - Lincoln. It has been accepted for inclusion in Papers in Natural Resources by an authorized administrator of DigitalCommons@University of Nebraska - Lincoln. 
Published in River Research and Applications 23 (2007), pp 786-791.

DOI 10.1002/rra.1002

Copyright (C) 2007 John Wiley \& Sons, Ltd. Used by permission.

Submitted 13 June 2006; revised 3 November 2006; accepted 21 December 2006;

published 25 June 2007.

\title{
Patterns of Fish Diversity in a Mainstem Missouri River Reservoir and Associated Delta in South Dakota and Nebraska, USA
}

\author{
Mark A. Kaemingk, Brian D. S. Graeb, \\ Christopher W. Hoagstrom and David W. Willis \\ Department of Wildlife and Fisheries Sciences, Box 2140B, South Dakota State \\ University, Brookings, SD 57007-1696, USA \\ Corresponding author - Brian D. S. Graeb, Department of Wildlife and Fisheries Sciences, \\ Box 2140B, South Dakota State University, Brookings, SD 57007-1696, USA. \\ email Brian.Graeb@sdstate.edu
}

\begin{abstract}
There is an expansive and expanding delta at the confluence of the Niobrara and Missouri Rivers in the Lewis and Clark Reservoir. The delta provides diverse aquatic habitat that is somewhat similar to the historic Missouri River and to remnant river habitats. As such, the delta may have relatively high fish species diversity compared to lentic reservoir habitats. To compare patterns of fish diversity between the delta and reservoir habitats, we collected fish in several nursery habitats in both areas using four gear types (seine, gill net, electrofisher and fyke net) on three occasions (July, August and September) in 2005. Species richness was higher in the delta $(n=34)$ than the reservoir $(n=22)$. Thirteen species composed more than $1 \%$ of delta collections while only four species composed more than $1 \%$ of reservoir collections. Species diversity (Fisher's a) was also significantly higher in the delta. Higher species diversity in the delta may be explained by higher habitat diversity. These results suggest that newly forming deltas have the potential to protect and restore fish species diversity, because they retain natural river functions such as sediment transport and habitat formation.
\end{abstract}

Keywords: Missouri River restoration, fish species diversity, reservoir delta 


\section{Introduction}

Across the world, dams are filling with sediment and as a result, novel delta habitats are forming in many systems (Palmieri et al., 2001). Sedimentation generally occurs over long temporal scales such that evidence of sedimentation is not readily apparent in some systems, but sedimentation will eventually occur in every reservoir constructed (Palmieri et al., 2001), and in some systems extensive deltas have already formed allowing researchers to begin studying the impacts of delta habitats on fish communities in reservoir systems. Lewis and Clark Reservoir, the most downstream of the mainstem Missouri River reservoirs, is one system where sedimentation has occurred relatively rapidly, resulting in the development of a delta. The delta in Lewis and Clark Reservoir is quite extensive (approximately $34 \mathrm{~km}$ ) and has formed as a result of sediment deposition from a large tributary to this system, the Niobrara River, which drains northern Nebraska from west to east. Aquatic habitats in the delta are diverse with abundant in-channel bedforms such as sand bars, side channels and backwaters that create a complex riverine landscape. This diverse riverscape has some similarities to the historical Missouri River (e.g. high sediment loads, high width-depth ratios, abundant sand substrate, several wetlands and aquatic vegetation) and habitat conditions are seemingly consistent with recommendations for habitat restoration elsewhere along the Missouri River (Harberg et al., 1993; Hesse and Sheets, 1993; Latka et al., 1993). Further, studies have shown that Missouri River reaches with braided river channels and a diversity of aquatic habitats within the floodplain have diverse fish communities (Schmulbach et al., 1975; Kallemeyn and Novotny, 1977; Jacobson et al., 2001) and are superior for sport fish production as compared to channelized and/or modified reaches (Groen and Schmulbach, 1978). Such reaches also support more diverse invertebrate communities (Morris et al., 1968).

Despite the similarity of the Niobrara River delta to remnant reaches of the Missouri River, fish assemblage studies have focused on tailwater fisheries upstream of or downstream from the Lewis and Clark delta (Walburg et al., 1971; Schmulbach et al., 1975; Kallemeyn and Novotny, 1977; Berry and Young, 2004), or solely on the reservoir (Walburg, 1976; Wickstrom, 2000, 2004). Thus, our objective was

to compare fish species diversity between the Lewis and Clark delta 
and reservoir habitats. We hypothesized that reservoir deltas represent additional areas where some ecological characteristics of the historic Missouri River persist (i.e. high species diversity), even though deltas occur in modified habitats (i.e. reservoirs), because they retain natural river functions such as sediment transport and habitat formation, which are disrupted in riverine sections of the Missouri River below dams.

\section{Methods}

Lewis and Clark Reservoir, located on the Missouri River along the South Dakota-Nebraska border, is the downstream most of seven mainstem reservoirs. The reservoir has a surface area of approximately $105 \mathrm{~km}^{2}$, maximum depth of $16.7 \mathrm{~m}$, and mean depth of $5.0 \mathrm{~m}$ (Wickstrom, 2004). Approximately $74 \mathrm{~km}$ of riverine habitat exist upstream from the reservoir to Fort Randall Dam. This riverine habitat is composed of two distinct segments: a delta that extends approximately $34 \mathrm{~km}$ above the reservoir, and the Missouri National Recreational River reach that encompasses the upper $40 \mathrm{~km}$ of this system. Our study focused on the delta and reservoir habitats of this system.

We collected fishes from nursery habitats at two delta stations and two reservoir stations (Figure 1). Sampling was conducted monthly from July through September 2005. Targeted nursery habitats included main channel margins, side channels, backwaters, river channel shoreline embayments, shallow pools among sandbars, and reservoir shorelines. We targeted shallow waters $(<1.5 \mathrm{~m})$ in these habitats using 3-mm bar mesh beach seines (3.7m long, 1.2m deep), a boat mounted electrofisher (Coffelt VVP-15 control unit; C-phase, pulsedDC current), modified fyke nets (1.5m by $0.8 \mathrm{~m}$ frames, $19-\mathrm{mm}$ bar mesh), and experimental gill nets (100m total length; $50 \mathrm{~m}$ of $0.32-\mathrm{cm}$ and $50 \mathrm{~m}$ of $0.65-\mathrm{cm}$ bar mesh). We standardized sampling effort during our study; we electrofished 10, 5-min runs per station, made 10 seine hauls (10-15 m) either upstream in areas with current, or perpendicular to shorelines in slack water habitat, and deployed four fyke nets and four gill nets for approximately $4 \mathrm{~h}$ per station. Our gear was effective for small-bodied fishes of all ages (e.g. shiners [Cyprinidae]) but for only juveniles of large-bodied fishes (e.g. largemouth bass $M i-$ cropterus salmoides). Thus, incidental catches of adult large-bodied 


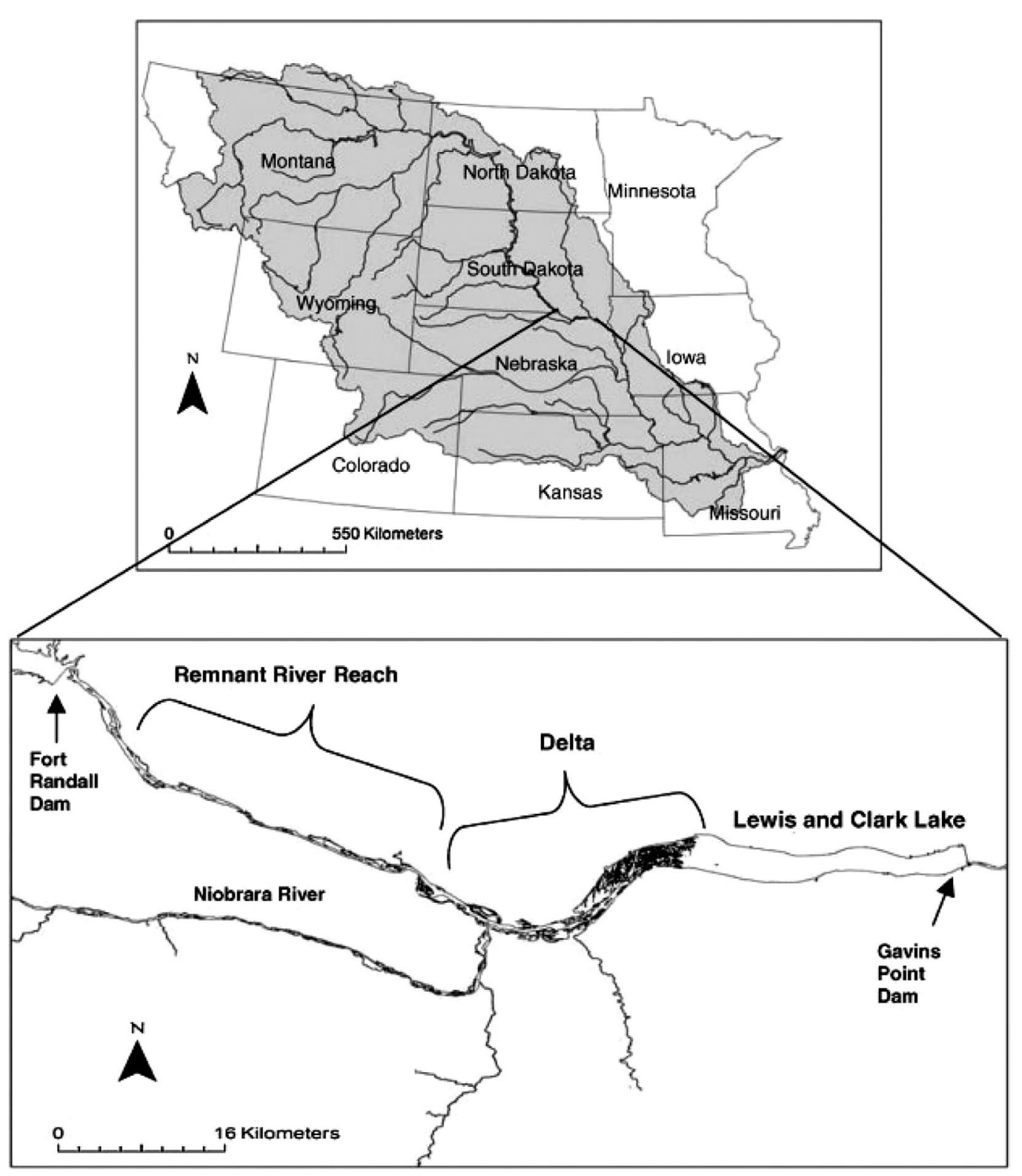

Figure 1. Lewis and Clark reservoir and Missouri River study area

fishes were not included in our analyses. Fishes were immediately preserved in 90\% ethanol and later identified to species and enumerated in the lab.

We analyzed fish species diversity as species richness (total number of species, number of common species) and species diversity (Fisher's a). Species richness is a common diversity measure, but it ignores differences in species dominance (MacArthur and MacArthur, 1961) 
and is affected by sample size (Preston, 1962). A simple summary of species richness may include incidental (nonresident) species. Thus, we also enumerated species that composed more than $1 \%$ (herein referred to as common species) of the total delta or reservoir sample (all months combined). Fisher's a provided a more rigorous estimate of species diversity as it represents species of average abundance (neither highly abundant species nor rare species) and is unaffected by sample size (Kempton and Taylor, 1974; Magurran, 1988). It is derived using the formula: $\alpha=N(1-x) / x$, where $x$ is from iterative solution of: $S / N=(1-x) / x[-\ln (1-x)]$, where $S=$ number of species and $N=$ number of individuals. Fisher's $\alpha$ values have the added benefit of potential for statistical comparison using confidence limits calculated as variance: $\operatorname{Var}(\alpha)=\alpha /-\ln (1-x)$ (Magurran, 1988).

\section{Results}

A total of 9788 individuals representing 37 fish species were collected (Table I). Overall, species richness was greater at the delta sites ( $n=$ 34) compared to the reservoir sites ( $n=22$; Table I). Species diversity (Fisher's a) was higher within the delta (mean \pm variance, $5.6 \pm 0.9$ ) than within the reservoir (mean \pm variance, $2.8 \pm 0.4$ ). Thirteen fish species were common ( $>1 \%$ total catch) in the delta (Table I). Four of these (gizzard shad Dorosoma cepedianum, emerald shiner Notropis atherinoides, white bass Morone chrysops, freshwater drum Aplodinotus grunniens) were also common in the reservoir. No species was common only in the reservoir.

\section{Discussion}

We found higher fish diversity in upstream delta habitats than reservoir habitats in Lewis and Clark Reservoir. Our findings corroborate other studies along the Missouri River in which fish species diversity was high in river reaches with high habitat diversity. Fish and wildlife productivity along the Missouri River declined due to effects of reservoir construction and operation (Funk and Robinson, 1974; Whitley and Campbell, 1974), but areas that maintained some characteristics of the historical Missouri River remain as strongholds of species 
Table I. Numbers of fish species collected at four stations (two delta, two reservoir) over three sampling periods (July, August, September) in 2005 at Lewis and Clark Reservoir, South Dakota. 'Common' fish species (defined as those that composed $>1 \%$ of the total sample at each habitat type (i.e. delta or reservoir) are denoted by asterisks. Relative abundance (\%) is noted in parentheses for each common species; all other species represented less than $1 \%$ of the relative abundance.

\begin{tabular}{|c|c|c|c|}
\hline Common name & Scientific name & Delta & Reservoir \\
\hline Shortnose gar & Lepisosteus platostomus & 2 & 3 \\
\hline Gizzard shad & Dorosoma cepedianum & $270(11)^{*}$ & $645(9)^{*}$ \\
\hline Central stoneroller & Campostoma anomalum & 2 & $\mathrm{o}$ \\
\hline Red shiner & Cyprinella lutrensis & $142(6)^{*}$ & 3 \\
\hline Spotfin shiner & Cyprinella spilopterus & $391(16)^{*}$ & 13 \\
\hline Common carp & Cyprinus carpio & 8 & 1 \\
\hline Brassy minnow & Hybognathus hankinsoni & 22 & $\mathrm{O}$ \\
\hline Silver chub & Macrhybopsis storeriana & o & 2 \\
\hline Golden shiner & Notemigonus crysoleucas & 4 & $\mathrm{O}$ \\
\hline Emerald shiner & Notropis atherinoides & $552(22)^{*}$ & $5890(81)^{*}$ \\
\hline River shiner & Notropis blennius & $163(6)^{*}$ & $\mathrm{o}$ \\
\hline Spottail shiner & Notropis hudsonius & $59(2)^{*}$ & 19 \\
\hline Sand shiner & Notropis stramineus & $50(2)^{*}$ & $\mathrm{O}$ \\
\hline Bluntnose minnow & Pimephales notatus & $39(1)^{*}$ & $\mathrm{O}$ \\
\hline Fathead minnow & Pimephales promelas & 16 & $\mathrm{O}$ \\
\hline Flathead chub & Hybopsis gracilis & $76(3)^{*}$ & $\mathrm{O}$ \\
\hline Bigmouth shiner & Notropis dorsalis & $35(1)^{*}$ & $\mathrm{o}$ \\
\hline Creek chub & Semotilus atromaculatus & $\mathrm{o}$ & 1 \\
\hline Carpsuckers $^{1}$ & Carpiodes spp. & $168(7)^{*}$ & $\mathrm{O}$ \\
\hline Smallmouth buffalo & Ictiobus bubalus & 12 & 7 \\
\hline Bigmouth buffalo & Ictiobus cyprinellus & 15 & 1 \\
\hline Shorthead redhorse & Moxostoma macrolepidotum & 10 & 1 \\
\hline Channel catfish & Ictalurus punctatus & 5 & 1 \\
\hline Flathead catfish & Pylodictus olivaris & $\mathrm{o}$ & 1 \\
\hline Northern pike & Esox lucius & 2 & $\mathrm{o}$ \\
\hline White bass & Morone chrysops & $68(3)^{*}$ & $542(8) *$ \\
\hline Rock bass & Ambloplites rupestris & 4 & $\mathrm{O}$ \\
\hline Orangespotted sunfish & Lepomis humilis & 4 & $\mathrm{O}$ \\
\hline Bluegill & Lepomis macrochirus & $49\left((2)^{*}\right.$ & 11 \\
\hline Smallmouth bass & Micropterus dolomieu & 25 & 3 \\
\hline Largemouth bass & Micropterus salmoides & $86(3)^{*}$ & 5 \\
\hline White crappie & Pomoxis annularis & 6 & $\mathrm{O}$ \\
\hline Black crappie & Pomoxis nigromaculatus & $75(3)^{*}$ & 14 \\
\hline Johnny darter & Etheostoma nigrum & $100(4)^{*}$ & 18 \\
\hline Yellow perch & Perca flavescens & 5 & $\mathrm{O}$ \\
\hline Sander ${ }^{2}$ & Sander spp. & 13 & 13 \\
\hline Freshwater drum & Aplodinotus grunniens & $34(1)^{*}$ & $82(1)^{*}$ \\
\hline Total & & 2,512 & 7,276 \\
\hline
\end{tabular}

1 Carpsuckers include river carpsucker Carpiodes carpio, quillback Carpiodes cyprinus, and highfin carpsucker Carpiodes velifer. Previous studies indicated that a majority of carpsuckers found in this region were river carpsuckers, but we were unable to differentiate between these species at small sizes (Schmulbach et al., 1975; Wickstrom, 2000, 2004).

2 Sander include walleye Sander vitreus, sauger Sander canadensis, and hybrids. Natural hybridization is known to occur in this system (Billington et al., 2004), so it is difficult to distinguish walleye, sauger and hybrids. 
diversity and rare native species (Schmulbach et al., 1975; Berry and Young, 2004; Everett et al., 2004; Welker and Scarnecchia, 2004). Although we are unaware of any previous investigations of fish diversity within delta habitats, our results are similar to a study conducted on plants wherein plant diversity was higher within delta habitats than reservoirs (Johnson, 2002). Moreover, Falke and Gido (2006) found higher fish species richness at the confluence of tributary streams with reservoirs than in the tributary streams themselves. These confluence habitats may be similar to the Niobrara River delta.

Our results (34 species in nursery habitats of the delta) compare favorably with results of a much larger study of the fish assemblage in the Missouri River upstream of the delta (43 species; Berry and Young, 2004) and with collections from Lewis and Clark Reservoir (37 species; Wickstrom, 2000, 2004). Most species found in other studies that we did not collect (pallid sturgeon Scaphirhynchus albus, shovelnose sturgeon Scaphirhynchus platorynchus, paddlefish Polyodon spathula, goldeye Hiodon alosoides, burbot Lota lota, stonecat Noturus flavus) are big river species, unlikely to occupy nursery habitats (Trautman, 1981; Pflieger, 1997). Others (mimic shiner Notropis volucellus, white sucker Catostomus commersonii, black bullhead Ameiurus melas, grass pickerel Esox americanus and green sunfish Lepomis cyanellus) were rare in earlier studies. We found one species (bigmouth shiner Notropis dorsalis) that was absent from other collections. Thus, the fish assemblage of the delta is similar to that of both the river upstream and reservoir downstream, but nursery habitats of the delta support more species than either of these habitats. We hypothesize that nursery habitats in the delta are important for fish populations of the entire Lewis and Clark Reservoir system.

We attribute high species diversity in nursery habitats of the delta compared to those of the reservoir to habitat diversity. For example the prevalent delta inhabitants red shiner Cyprinella lutrensis, spotfin shiner Cyprinella spiloptera, river shiner Notropis blennius, and river carpsucker Carpiodes carpio primarily inhabit flowing waters (Trautman, 1981; Pflieger, 1997). In contrast, the prevalent spottail shiner Notropis hudsonius, largemouth bass Micropterus salmoides, black crappie Pomoxis nigromaculatus, and johnny darter Etheostoma nigrum are characteristic of habitats with little or no current (Trautman, 1981; Pflieger, 1997). The presence of interspersed fluvial habitat and slackwater habitat in the delta evidently contributes to higher 
overall species diversity by supporting both flowing water and slackwater fishes. Further, the prevalence of dominant reservoir fishes (gizzard shad, emerald shiner, white bass, freshwater drum) in the delta suggests a link between delta and reservoir fish communities.

Our fish collection occurred only during summer and early fall because we were very interested in including age-o fishes in our assessment. However, temporal variability in fish species composition may occur throughout the early growing season (spring) and overwinter periods that may affect patterns of fish diversity. Future studies that incorporate expanded temporal coverage of delta and reservoir habitats will increase our understanding of the relative importance of these habitats.

Fish conservation and management along the Missouri River is complex due to the changes and diversity in regulatory agencies involved (McClendon, 1976; Hesse et al., 1989; Galat et al., 2005). However, many researchers agree that habitat diversity and a complex riverine landscape correspond with higher ecological productivity and fish species diversity in the Missouri River (Morris et al., 1968; Funk and Robinson, 1974; Schmulbach et al., 1975; Kallemeyn and Novotny, 1977; Groen and Schmulbach, 1978; Hesse et al., 1988; Brown and Coon, 1994; Galat et al., 1998; Fisher and Willis, 2000; Welker and Scarnecchia, 2003; Dieterman and Galat, 2004).We contend that reservoir deltas may play a role in Missouri River fish conservation and management by increasing aquatic habitat diversity via passive rehabilitation (sensu Jacobson et al., 2001) because the natural processes of sediment transport and habitat formation are present and dynamic in the delta. As a result, reservoir deltas may increase management options and provide unique opportunities for studies of ecological processes.

Acknowledgments - The authors thank J. Roddy, B. Temple and T. Selch for field assistance. B. Spindler provided G.I.S. support. The South Dakota Department of Game, Fish and Parks provided partial funding through Federal Aid in Sport Fish Restoration Project F-15-R, Study 1599. The National Parks Service also provided partial funding for this project through the Great Plains Cooperative Ecosystems Studies Unit Task Agreement No. J6288060003. 


\section{References}

Berry CR Jr, Young B. 2004. Fishes of the Missouri national recreational river, south Dakota and Nebraska. Great Plains Research 14: 89-114.

Billington N, Koigi RN, Graeb BDS, Willis DW. 2004. Hybridization between sauger and walleye in Lewis and Clark Lake, South Dakota, determined by protein electrophoresis. In Proceedings of Percis III: The Third International Percid Fish Symposium, Barry TP, Malison JA (eds). University of Wisconsin Sea Grant Institute: Madison, WI; 115-116.

Brown DJ, Coon TG. 1994. Abundance and assemblage structure of fish larvae in the lower Missouri River and its tributaries. Transactions of the American Fisheries Society 123: 718-732.

Dieterman DJ, Galat DL. 2004. Large-scale factors associated with sicklefin chub distribution in the Missouri and lower Yellowstone rivers. Transactions of the American Fisheries Society 133: 577-587.

Everett SR, Scarnecchia DL, Ryckman LF. 2004. Distribution and habitat use of sturgeon chubs (Macrhybopsis gelida) and sicklefin chubs (M. meeki) in the Missouri and Yellowstone Rivers, North Dakota. Hydrobiologia 527: 183-193.

Falke JA, Gido KB. 2006. Effects of reservoir connectivity on stream fish assemblages in the Great Plains. Canadian Journal of Fisheries and Aquatic Sciences 63: 480-493.

Fisher SJ, Willis DW. 2000. Seasonal dynamics of aquatic fauna and habitat parameters in a perched upper Missouri River wetland. Wetlands 20: 470-478.

Funk JL, Robinson JW. 1974. Changes in the channel of the lower Missouri River and effects on fish and wildlife. Aquatic Series No. 11. Missouri Department of Conservation: Jefferson City, MO.

Galat DL, Fredrickson LH, Humburg DD, Bataille KJ, Bodie JR, Dohrenwend J, Gelwicks GT, Havel JE, Helmers DL, Hooker JB, Jones JR, Knowlton MF, Kubisiak J, Mazourek J, McColpin AC, Renken RB, Semlitsch RD. 1998. Flooding to restore connectivity of regulated, large-river wetlands. BioScience 48: 721-733.

Galat DL, Berry CR Jr, Gardner WM, Hendrickson JC, Mestl GE, Power GJ, Stone C, Winston MR. 2005. Spatiotemporal patterns and changes in Missouri River fishes. American Fisheries Society Symposium 45: 249-291.

Groen CL, Schmulbach JC. 1978. The sport fishery of the unchannelized and channelized middle Missouri River. Transactions of the American Fisheries Society 107: 412-418.

Harberg MC, Remus JI, Rothe SC, Becic J, Hesse LW. 1993. Restoration planning for an abandoned Missouri River chute. In Restoration Planning for the Rivers of the Mississippi River Ecosystem, National Biological Survey Biological Report 19, Hesse LW, Stalnaker CB, Benson NG, Zuboy JR, (eds). U.S. Department of Interior: Washington, D.C.; 360-371.

Hesse LW, Sheets W. 1993. The Missouri River hydrosystem. Fisheries (Bethesda) 18(5): 5-14.

Hesse LW, Wolfe CW, Cole NK. 1988. Some aspects of energy flow in the Missouri River ecosystem and a rationale for recovery. In The Missouri River: The Resources, Their Uses and Values, North Central Division Special Publication No. 8, Benson NG (ed.). American Fisheries Society: Bethesda, MD; 13-29. 
Hesse LW, Schmulbach JC, Carr JM, Keenlyne KD, Unkenholz DG, Robinson JW, Mestl GE. 1989. Missouri River fishery resources in relation to past, present, and future stresses. In Proceedings of the International Large River Symposium, Canadian Special Publication of Fisheries and Aquatic Sciences 106, Dodge DP (ed.). Department of Fisheries and Oceans: Ottawa, Canada; 352-371.

Jacobson RB, Laustrup MS, Chapman MD. 2001. Fluvial processes and passive rehabilitation of the Lisbon Bottom side-channel chute, lower Missouri River. In Geomorphic Processes and Riverine Habitat, Water Science and Application 4, Dorava JM, Montgomery DR, Palcsak BB, Fitzpatrick FA (eds). American Geophysical Union: Washington, D.C.; 199-216.

Johnson WC. 2002. Riparian vegetation diversity along regulated rivers: contribution of novel and relict habitats. Freshwater Biology 47: 749-759.

Kallemeyn LW, Novotny JF. 1977. Fish and fish food organisms in various habitats of the Missouri River in South Dakota, Nebraska, and Iowa. FWS/OBS-77. U.S. Fish and Wildlife Service: Washington, D.C.

Kempton RA, Taylor LR. 1974. Log-series and log-normal parameters as diversity discriminants for the Lepidoptera. Journal of Animal Ecology 43: 381-399.

Latka DC, Nestler J, Hesse LW. 1993. Restoring physical habitat in the Missouri River: a historical perspective. In Restoration Planning for the Rivers of the Mississippi River Ecosystem, National Biological Survey Biological Report 19, Hesse LW, Stalnaker CB, Benson NG, Zuboy JR (eds). U.S. Department of Interior: Washington, D.C.; 350-359.

MacArthur RH, MacArthur JW. 1961. On bird species diversity. Ecology 42: 594-598.

Magurran AE. 1988. Ecological Diversity and its Measurement. Princeton University Press: Princeton, NJ.

McClendon EW. 1976. Conflicts and compatibilities associated with regulating the Missouri River mains stem reservoir system to enhance the fishery resource. In Instream Flow Needs, Volume II, Orsborn JW, Allman CD (eds). American Fisheries Society: Bethesda, MD; 148-157.

Morris LA, Langemeier RN, Russell TR, Witt A Jr. 1968. Effects of main stem impoundments and channelization upon the limnology of the Missouri River, Nebraska. Transactions of the American Fisheries Society 97: 380-388.

Palmieri A, Shah F, Dinar A. 2001. Economics of reservoir sedimentation and sustainable management of dams. Journal of Environmental Management 61: 149-163.

Pflieger WL. 1997. The Fishes of Missouri. Missouri Department of Conservation: Jefferson City, MO.

Preston FW. 1962. The canonical distribution of commonness and rarity: part I. Ecology 43: 85-215.

Schmulbach JC, Gould G, Groen CL. 1975. Relative abundance and distribution of fishes in the Missouri River, Gavins Point Dam to Rulo, Nebraska. Proceedings of the South Dakota Academy of Science 54: 194-222.

Trautman MB. 1981. The Fishes of Ohio. Ohio State University Press: Columbus, $\mathrm{OH}$. 
Walburg CH. 1976. Changes in the fish population of Lewis and Clark Lake, 195674 , and their relation to water management and the environment. Research Report 79. U.S. Fish and Wildlife Service: Washington, D.C.

Walburg CH, Kaiser GL, Hudson PL. 1971. Lewis and Clark Lake tailwater biota and some relations of the tailwater and reservoir fish populations. In Reservoir Fisheries and Limnology, Special Publication No. 8, Hall GE (ed.). American Fisheries Society: Bethesda, MD; 449-467.

Welker TL, Scarnecchia DL. 2003. Differences in species composition and feeding ecology of catostomid fishes in two distinct segments of the Missouri River, North Dakota, U.S.A. Environmental Biology of Fishes 68: 129-141.

Welker TL, Scarnecchia DL. 2004. Habitat use and population structure of four native minnows (family Cyprinidae) in the upper Missouri and lower Yellowstone rivers, North Dakota (USA). Ecology of Freshwater Fish 13: 8-22.

Whitley JR, Campbell RS. 1974. Some aspects of water quality and biology of the Missouri River. Transactions of the Missouri Academy of Science 7-8: 60-72.

Wickstrom G. 2000. Annual fish population surveys of Lewis and Clark Lake and Missouri River creel surveys. Fisheries Division Report oo-17. South Dakota Department of Game, Fish and Parks: Pierre, SD.

Wickstrom G. 2004. Annual fish population surveys of Lewis and Clark Lake. Fisheries Division Report 05-15. South Dakota Department of Game, Fish and Parks: Pierre, SD. 